\title{
Surgical Management of Intracranial Arachnoid Cysts: Clinical and Radiological Outcome
}

\author{
Intrakraniyal Araknoid Kistlerin Cerrabi Tedavisi: Klinik ve Radyolojik \\ Sonuç
}

Imad Saeed KHAN, Ashish SONIG, Jai Deep THAKUR, Anil NANDA

Louisiana State University, Health Sciences Center, Department of Neurosurgery, Shreveport, LA, USA

Presented in: Portions of this work will be presented in an e-poster form at the 80th AANS Annual Scientific Meeting at Miami, Florida, April 14-18, 2012.

Correspondence address: Anil NANDA / E-mail: ananda@1suhsc.edu

\begin{abstract}
AIM: Intracranial arachnoid cysts account for $1 \%$ of all intracranial mass lesions and may require drainage if symptomatic.

MATERIAL and METHODS: We retrospectively reviewed the medical records of 45 consecutive patients who underwent surgical drainage for symptomatic intracranial cysts at our institution from January 2000 to January 2010. The average age of our patients was 36.2 years; 26 were female and 19 were males. The most common symptoms included headaches (73.3\%) and dizziness (35.6\%).

RESULTS: Cyst wall fenestration was carried out in 29 (64.4\%), Cystoperitoneal shunting in $6(13.3 \%)$ and endoscopic fenestration and stealth guided craniotomy in 5 patients each (11.1\%). Seven patients had perioperative complications, and on discharge $79.1 \%$ of all patients had partial or complete clinical relief and $85.7 \%$ showed radiological decompression. A maximum cyst dimension of more than $5.0 \mathrm{~cm}$ was significantly associated with worse outcome at discharge $(p=0.02)$. There was no association between post-operative size cyst decompression and resolution of clinical symptoms. The clinical and radiological outcomes were comparable between different surgical methods.

CONCLUSION: There was no difference in the outcomes between different modalities. The extent of post-operative radiological reduction had no correlation with clinical outcomes, and should be assessed in relation to the patient's clinical status.
\end{abstract}

KEYWORDS: Intracranial arachnoid cyst, Outcomes, Radiological, Clinical

öz

AMAÇ: İntrakraniyal araknoid kist tüm intrakraniyal kitle lezyonlarının \%1'ini oluşturur ve semptomatikse drenajı gerekebilir.

YÖNTEM ve GEREÇLER: Kurumumuzda Ocak 2000 ile Ocak 2010 arasında semptomatik intrakraniyal kistler için cerrahi drenaj yapılan arka arkaya 45 hastanın tıbbi kayıtlarını retrospektif olarak inceledik. Hastalarımızın ortalama yaşı 36,2 yıldı; 26'sı kadın ve 19'u erkekti. En sık görülen belirtiler arasında başağrısı $(\% 73,3)$ ve başdönmesi $(\% 35,6)$ vardı.

BULGULAR: Kist duvarı fenestrasyonu $29(\% 64,4)$ hastada, Kistoperitoneal şant $(\% 13,3)$ hastada ve endoskopik fenestrasyon ve stealth kılavuzlu kraniyatomi her biri 5 hastada $(\% 11,1)$ yapıldı. Yedi hastanın perioperatif komplikasyonları vardı ve taburcu olma sırasında hastaların $\% 79,1^{\prime}$ i kısmi veya tam klinik iyileşme yaşarken \%85,7'si radyolojik dekompresyon gösteriyordu. Maksimum kist boyutunun 5,0 cm'den fazla olması taburcu olma zamanında daha kötü bir sonuçla anlamlı derecede ilişkiliydi $(p=0,02)$. Postoperatif büyüklükle kist dekompresyonu ve klinik belirtileri geçmesi arasında ilişki yoktu. Klinik ve radyolojik sonuçlar farklı cerrahi yöntemler arasında benzerdi.

SONUÇ: Farklı modaliteler arasında sonuç farkı yoktu. Postoperatif radyolojik küçülme miktarının klinik sonuçlarla bir ilişkisi yoktu ve bunun hastanın klinik durumuna göre değerlendirilmesi gerekir.

ANAHTAR SÖZCÜKLER: İntrakraniyal araknoid kist, Sonuçlar, Radyolojik, Klinik

\section{INTRODUCTION}

Arachnoid cysts are benign congenital malformations leading to a collection of cerebrospinal fluid (CSF) within the arachnoid membrane and subarachnoid space $(20,27)$. Newer imaging modalities have depicted a higher incidence of intracranial arachnoid cysts than was previously thought (6). Arachnoid cysts form approximately $1 \%$ of all intracranial masses, and the overall male to female predominance is $2: 1(1,20)$. They are usually situated in the cisterns and major cerebral fissures; the temporal fossa is the most common site (30).
Arachnoid cysts may be completely asymptomatic or present with a myriad of symptoms (20). The clinical picture might be predominated by nonspecific symptoms of increased intracranial pressure, such as headaches and dizziness (13). Others can present with focal neurological deficits, epilepsy, and hydrocephalus $(4,16)$. Arachnoid cysts have also been strongly linked to a reversible dyscognition in patients (33). A positive correlation between the intracystic pressure and the level of preoperative complaints has been reported (14). 
The management of intracranial arachnoid cysts has been controversial (22). Some have cited the risk of increased risk of rupture of arachnoid cysts as reason for early surgical intervention, even in asymptomatic patients (28). Studies have on the natural history of the cysts have been few (3) but favor a more conservative approach (25). Surgical management of symptomatic intracranial arachnoid cysts is now being preferred on the back of reports of safe and efficacious surgical procedures (13). Surgical drainage can be achieved with stereotactic fenestration, craniotomy with microsurgical cyst fenestration, or cystoperitoneal or cystosubdural shunt $(6,13,17,20)$. A good understanding of the pathophysiology behind the expansion of the arachnoid cysts may help in deciding between the various surgical decompression modalities available (6).

Our institutional policy is to offer surgery if the clinical symptoms are severe and have not responded to conservative measures, or if the patient presents with epilepsy, hydrocephalus or focal neurological deficits. The aim of our study was to review our institutional experience with the surgical management of intracranial arachnoid cysts with respect to the clinical and radiological outcomes.

\section{MATERIAL and METHODS}

\section{Subjects}

We conducted a retrospective study of patients with intracranial arachnoid cysts that underwent decompression at our institution from January 2000 to January 2010. The patients were identified from a prospectively collected database and their medical records were retrospectively reviewed after acquiring approval from the Institutional Review Board of Louisiana State University, Shreveport, LA. We collected data on basic demographics, presenting signs and symptoms, operative details, and hospital course. The clinical and radiological outcome at discharge was recorded. The patients were followed clinically after discharge and their clinical outcome documented at last follow-up. The mean follow-up in our patients was 18.5 months (range $=1$ - 96). The patients also underwent radiological investigation between 3 to 6 months postoperatively to document the radiological outcome. Six patients were lost to follow-up in our study.

Forty-five consecutive patients were included in the study with mean age of 36.2 years (range $=0.2-71$ ); 26 were female and 19 were males. The presenting features of the patients are summarized in Table I. One patient, a 3 year old boy, was asymptomatic but the arachnoid cyst increased in size on serial imaging and due to marked compression of the adjacent brain parenchyma, we felt it prudent to proceed with surgical decompression. The location of the arachnoid cyst was supratentorial and infratentorial in twenty-three, and twenty-two patients, respectively (Table II).

\section{Procedures}

Four types of procedures were performed. Overall the most commonly performed procedure was craniotomy with cyst wall fenestration in 29 patients (64.4\%). Cystoperitoneal shunting was carried out in six patients (13.3\%). We carried out endoscopic fenestration and stealth guided craniotomy in five patients each (11.1\%). The most commonly performed procedure in supratentorial and infratentorial arachnoid cysts was craniotomy with cyst wall fenestration (Table IV).

\section{Terms and measures}

Clinical outcome was documented at discharge and last follow-up. We divided the clinical outcome into three categories compared to their preoperative clinical status: improved, no change, or worsened. The neurological outcome was documented at discharge and between 3-6 months after follow-up (Figure $1 \mathrm{~A}, \mathrm{~B}, \mathrm{C}$ ). The radiological status was recorded in terms of the size of the cyst compared to the preoperative

Table I: Preoperative Characteristics of Patients

\begin{tabular}{|c|c|}
\hline Characteristics & $\mathbf{N}=45$ \\
\hline Age (years) & $36.2 \pm 19.9(0.2-71)^{*}$ \\
\hline Sex: N (\%) & $19(42.2 \%)$ \\
Male & $26(57.8 \%)$ \\
Female & \\
\hline Signs and symptoms: N (\%) & $33(73.3 \%)$ \\
Headache & $16(35.6 \%)$ \\
Dizziness & $12(26.7 \%)$ \\
Visual symptoms & $7(15.6 \%)$ \\
Motor or sensory disturbances & $6(13.3 \%)$ \\
Seizures & $6(13.3 \%)$ \\
Nausea and vomiting & $4(8.9 \%)$ \\
Hearing difficulties & $3(6.7 \%)$ \\
Syncope & $3(6.7 \%)$ \\
Neck stiffness & $3(6.7 \%)$ \\
Dyscognition & $3(6.7 \%)$ \\
Hydrocephalus & $1(2.2 \%)$ \\
Asymptomatic & $31(68.9 \%)$ \\
Patients with > 1 symptoms on & \\
presentation & \\
$\mathbf{N}=$ number of patients, ${ }^{*}$ Mean \pm Standard deviation (range).
\end{tabular}

Table II: Location of Arachnoid Cysts

\begin{tabular}{|c|c|}
\hline Parameters & $N=45$ \\
\hline \multicolumn{2}{|c|}{ Cyst location: N (\%) } \\
\hline $\begin{array}{l}\text { Infratentorial } \\
\text { Right } \\
\text { Left } \\
\text { Midline }\end{array}$ & $\begin{array}{r}22(48.9 \%) \\
8(17.8 \%) \\
5(11.1 \%) \\
9(20.0 \%)\end{array}$ \\
\hline $\begin{array}{l}\text { Supratentorial } \\
\text { Temporal } \\
\text { Frontal } \\
\text { Occipital } \\
\text { Suprasellar } \\
\text { Other }\end{array}$ & $\begin{array}{c}23(51.1 \%) \\
13(28.9 \%) \\
5(11.1 \%) \\
2(4.4 \%) \\
2(4.4 \%) \\
1(2.2 \%)\end{array}$ \\
\hline
\end{tabular}

$\mathbf{N}=$ number of patients. 
size: cyst size decreased or no change in the size. For analysis we used improved clinical status as a good outcome, and no change or worsened clinical symptoms as poor outcome.

\section{Statistical tests}

Statistical analyses were performed with SPSS 20.0 for Windows. An a-level of 0.05 was used for statistical calculation. Contingency tables were analyzed with Fisher's exact test or $\mathrm{x}^{2}$ statistics.

\section{RESULTS}

Postoperatively all patients had either an improvement of clinical symptoms or a decrease in the size of their cysts, or both. We did not find any association between the type of surgery and clinical or radiological outcome. On discharge, $79.1 \%$ of all patients had partial or complete clinical relief and $85.7 \%$ showed radiological decompression. Postoperatively, cysts less than $2.5 \mathrm{~cm}$ in maximum dimension had a higher incidence of complete obliteration $(p=0.0079$, two-tailed Fisher Exact) at discharge.

At the last follow-up, $73.6 \%$ of the patients had partial or relief of symptoms and $77.8 \%$ of the patients had a decreased cyst

Table III: Preoperative Symptoms and Location of the Arachnoid Cyst

\begin{tabular}{|l|c|c|}
\hline Complaint & \multicolumn{2}{|c|}{ Location of cyst } \\
\hline & $\begin{array}{c}\text { Supratentorial: } \\
\mathbf{N}(\%)\end{array}$ & $\begin{array}{c}\text { Infratentorial: } \\
\mathbf{N}(\%)\end{array}$ \\
\hline Headaches & $16(69.6)$ & $17(77.3)$ \\
Dizziness & $6(26.1)$ & $10(45.5)$ \\
Vision complaints & $7(30.4)$ & $5(22.7)$ \\
Epilepsy & $4(17.4)$ & $2(9.1)$ \\
Dyscognition & $2(8.7)$ & $2(9.1)$ \\
Hydrocephalus & $1(4.3)$ & $2(9.1)$ \\
\hline
\end{tabular}

$\boldsymbol{N}=$ number of patients.
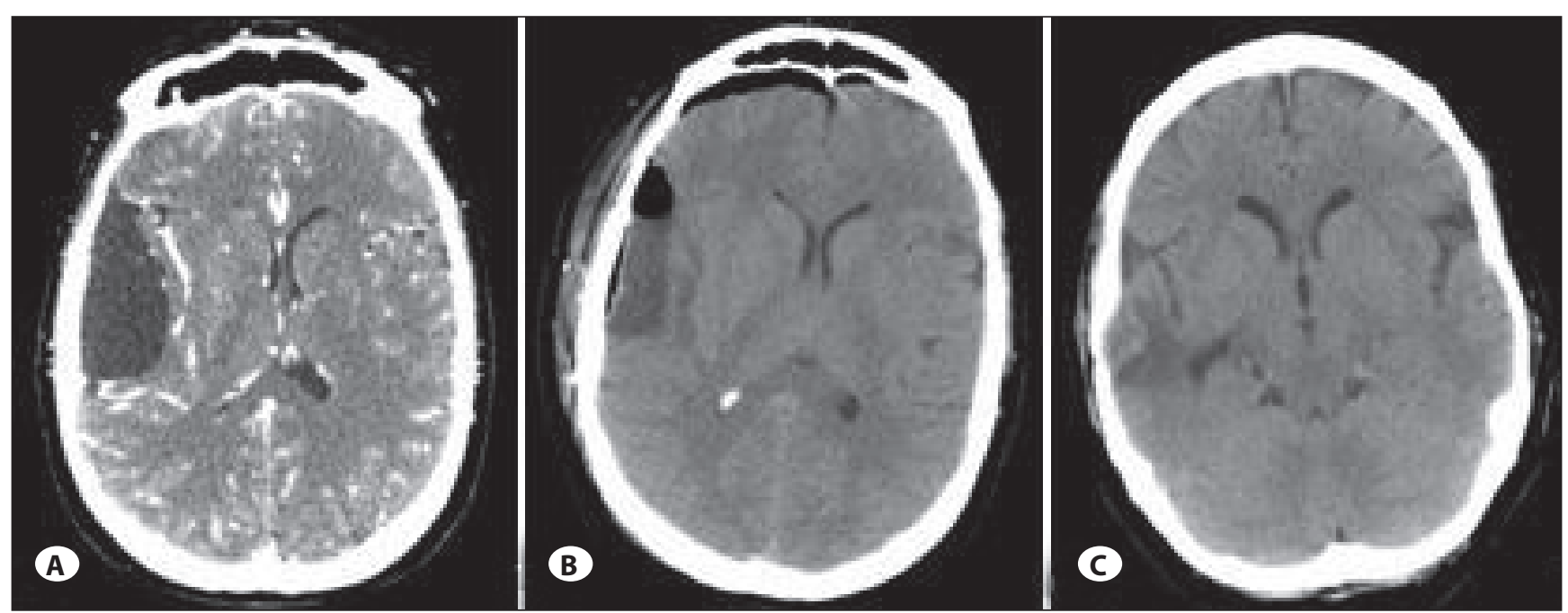

Figure 1: A 21-year-old female, presented with headaches and episodes and bilateral mild upper limb weakness (A). Preoperative CT shows a temporal fossa arachnoid cyst with mass effect (B). Postoperatively the cyst had decreased in size (C). On follow-up the cyst is nearly completely obliterated. 
data for 20 patients; fourteen of them had an improvement in their clinical symptoms compared to their preoperative status (70.0\%).

\section{Infratentorial Cysts}

The most common symptoms in infratentorial arachnoid cysts were headaches in $77.3 \%$ and dizziness in $45.5 \%$ (Table III). The average largest dimension of these cysts was 41.0 $\mathrm{mm}$ (range: 20-63). Of the 22 patients with infratentorial arachnoid cysts, 18 had clinical improvement (81.8\%) and 16 depicted a decrease in their cyst sizes $(72.7 \%)$ at discharge. We had follow-up data of 19 patients; fourteen of them had an improvement in their clinical symptoms (72.7\%).

\section{Complications}

Seven patients had perioperative complications, but there were no permanent neurological complications or mortalities (Table V). Three patients developed pseudomeningoceles after the surgery. One had to undergo surgical repair and the rest were managed conservatively with closed subarachnoid drainage. Three patients had infections in the postoperative period. One patient also developed diabetes insipidus postoperatively that resolved on follow-up. None of our patients had postoperative subdural hydromas, hematomas or empyemas.

\section{Re-operations}

Three patients underwent reoperations; all had an infratentorial arachnoid cyst. One patient, a 21 year old female, underwent a suboccipital craniotomy with partial cyst wall excision to relieve her headaches and dizziness. The patient had a relief of these symptoms at discharge but the cyst showed no decrease in size. She remained symptom free for the next 6 years and the cyst remained stable in size. Eighty months after her initial surgery however, she had a recurrence of her headaches, and the cyst showed an increase in size with a mass effect of the adjacent brain parenchyma. She underwent another craniotomy with excision of the cyst wall. The patient has had a relief of symptoms and a moderate decrease in the size of her cyst size at the latest follow-up at 6 months.

Another patient, 34 year old female, presented with an infratentorial arachnoid cyst and hydrocephalus. She subsequently underwent craniotomy and partial excision of the cyst wall. The surgery was successful in providing partial relief and a slight decrease in the size of the cyst, but the hydrocephalus did not resolve. She had to undergo a ventriculoperitoneal shunt placement to relieve the hydrocephalus. The third patient had a re-operation to repair a postoperative pseudomeningocele.

\section{DISCUSSION}

While some arachnoid cysts remain static in size, others can grow and compress adjacent brain parenchyma (32). Various mechanisms have been proposed for the growth of the arachnoid cysts. A higher concentration of sodium and protein in the cyst has been hypothesized to lead to an osmotic gradient and cause sodium growth (7). Ectopic choroid-like structures (more common in posterior fossa cysts) or the arachnoid wall is thought to actively secrete CSF as well $(9,20)$. A ball-and-valve mechanism which allows unidirectional flow into the cyst during valsalva has been observed intraoperatively $(21,23,24)$.

Most of our patients had a good clinical outcome postoperatively (partial or complete resolution of symptoms) at discharge and follow-up. A majority of the patients also showed a decrease in the size of the cyst. The site of the arachnoid cyst in relation with the tentorium had no bearing on the severity of symptoms in our patients. The most common symptom remained headache in our study population, as has been shown in earlier studies (13). Three of our patients

Table V: Perioperative Complications of Surgical Drainage

\begin{tabular}{|c|c|c|c|}
\hline Patient & Cyst site & Surgery type & Complications \\
\hline $54, f$ & Petrous apex & Craniotomy with cyst wall excision & $\begin{array}{l}\text { CSF leak; managed with a closed subarachnoid } \\
\text { cyst drainage }\end{array}$ \\
\hline $36, f$ & Frontal & Craniotomy with cyst wall excision & $\begin{array}{l}\text { Pseudomeningocele; managed with a closed } \\
\text { subarachnoid cyst drainage }\end{array}$ \\
\hline $29, \mathrm{~m}$ & Posterior fossa & Craniotomy with cyst wall excision & Pseudomeningocele; required surgical correction \\
\hline $11, \mathrm{~m}$ & Frontal & Cystoperitoneal shunt & $\begin{array}{l}\text { Shunt infection and meningitis; cultures grew } \\
\text { MRSA; shunt removed }\end{array}$ \\
\hline $38, f$ & Posterior fossa & Cystoperitoneal shunt & $\begin{array}{l}\text { Shunt infection; developed sepsis and } \\
\text { multisystem failure; admitted to ICU and treated } \\
\text { with antibiotics and removal of shunt }\end{array}$ \\
\hline $61, \mathrm{~m}$ & $\begin{array}{l}\text { Cerebellopontine } \\
\text { angle }\end{array}$ & Craniotomy with cyst wall excision & $\begin{array}{l}\text { Wound dehiscence and meningitis; wound } \\
\text { revision and antibiotics }\end{array}$ \\
\hline $53, \mathrm{f}$ & Suprasellar & Craniotomy with cyst wall excision & Transient diabetes insipidus \\
\hline
\end{tabular}


had cysts associated with hydrocephalus. The association between the two is thought to be secondary to disturbance in the CSF flow dynamics in these patients (16). Some preferred using cystoperitoneal shunting in these patients $(7,12)$, while others have maintained that endoscopic fenestration allows the concomitant treatment of the hydrocephalus in the same setting (16).

The surgical management of the arachnoid cyst centers on surgically communicating the cyst with the basal cisterns or the ventricular system (8). Craniotomy with microsurgical fenestration is the conventional treatment modality and allows the option of removing the cyst wall (20). This may be beneficial if there is active secretion of CSF from the cyst wall or ectopically placed choroid-like structure (9). However complete removal of the cyst wall is often not possible and often only a partial excision of the cyst is sufficient for an adequate decompression of the cyst (25). In our experience, fenestration of the cyst wall was sufficient to provide long term clinical relief to most patients.

Fenestration of the cyst wall is also possible through microsurgical keyhole craniotomy, stereotactic aspiration or endoscopic techniques $(6,20,25)$. While these procedures are relatively newer, studies have shown comparable results to older modalities with a low risk of complication $(11,25)$. Open craniotomy procedures may allow a better control of bleeding in patients $(6,13)$. Our institution now utilizes stereotaxy and endoscopy for arachnoid cyst management with similar results to conventional craniotomy.

Arachnoid cysts can also be adequately decompressed using cystoperitoneal shunting as well. While there are various reports of this modality being safe and efficacious, there remain concerns over life-long shunt dependency $(2,4,15)$. The incidence of shunt revision in these patients is approximately $30 \%$ (20). Internal shunts to the subdural compartment have also been used successfully under local anesthesia for supratentorial arachnoid cysts $(13,29)$. Shunt placement can be assisted with stereotactic and endoscopic techniques in a few cases $(5,34)$.

Smaller sized arachnoid cysts ( $<2.5 \mathrm{~cm}$ maximum dimension) had a higher incidence of complete obliteration at discharge. This can be explained by the already small volumes of the cyst that were quickly decompressed. At the last follow-up, there was no difference in the rate of complete obliteration between the cysts of different sizes. Patients with cysts more than $5.0 \mathrm{~cm}$ in maximum dimension preoperatively did worse clinically at discharge. There was no difference at follow-up. With the relatively larger sizes of the cyst and more mass effect, the clinical resolution might have taken longer in these patients.

There was no association between the postoperative radiological and the clinical outcomes in our study. The lack of radiological decompression predicting the clinical status postoperatively echoes findings of other reports $(13,19,26)$. Contrary to this, some studies have found a close association between the two parameters $(10,18,31)$. Any apparent disassociation can be explained due to the fact that the molding of the neurocranium is determined by contents of the brain. Due to this, even when a congenital arachnoid cyst is decompressed, the rest of the brain might not have the volume to take up freed the space (13). It is because of this reason we believe that even though postoperative radiological status is an important tool in assessing outcome, findings should be taken in context of the patients' clinical condition.

This study describes our institutional experience over the last ten years. Most of our patients were managed adequately with craniotomy and fenestration of the cyst wall into the basal cisterns or ventricular system without any major complications. Endoscopic and stereotactic procedures have given similar results.

\section{CONCLUSION}

Arachnoid cysts are relatively common intracranial mass occupying lesions. When symptomatic, surgical decompression can lead to relief of symptoms. Radiological outcomes may not mirror the clinical outcome of the patients and should be interpreted cautiously. Open fenestration of the cyst into the basal cisterns or ventricular system leads to a good clinical and radiological outcome. Less invasive modalities such as endoscopic or stereotactic procedures give similar results and are now being used more commonly.

\section{REFERENCES}

1. Albuquerque FC, Giannotta SL: Arachnoid cyst rupture producing subdural hygroma and intracranial hypertension: Case reports. Neurosurgery 41:951-955; discussion 955-956, 1997

2. Alexiou $G A$, Varela $M$, Sfakianos $G$, Prodromou $N$ : Shunting for the treatment of arachnoid cysts in children. Neurosurgery 67:1632-1636; discussion 1636, 2010, 10.1227/ NEU.0b013e3181f94476

3. Al-Holou WN, Yew AY, Boomsaad ZE, Garton HJL, Muraszko KM, Maher CO: Prevalence and natural history of arachnoid cysts in children. J Neurosurg Pediatr 5:578-585, 2010, 10.3171/2010.2.PEDS09464

4. Arai H, Sato K, Wachi A, Okuda O, Takeda N: Arachnoid cysts of the middle cranial fossa: Experience with 77 patients who were treated with cystoperitoneal shunting. Neurosurgery 39:1108-1112; discussion 1112-1113, 1996

5. Berlis A, Vesper J, Ostertag C: Stent placement for intracranial cysts by combined stereotactic/endoscopic surgery. Neurosurgery 59:ONS474-479; discussion ONS479-480, 2006, 10.1227/01.NEU.0000233694.52492.74

6. Boutarbouch M, El Ouahabi A, Rifi L, Arkha Y, Derraz S, El Khamlichi A: Management of intracranial arachnoid cysts: Institutional experience with initial 32 cases and review of the literature. Clin Neurol Neurosurg 110:1-7, 2008, 10.1016/j. clineuro.2007.08.009 
7. Caemaert J, Abdullah J, Calliauw L, Carton D, Dhooge C, van Coster R: Endoscopic treatment of suprasellar arachnoid cysts. Acta Neurochir (Wien) 119:68-73, 1992

8. Cincu R, Agrawal A, Eiras J: Intracranial arachnoid cysts: Current concepts and treatment alternatives. Clin Neurol Neurosurg 109:837-843, 2007, 10.1016/j.clineuro.2007.07.013

9. Dei-Anang K, Voth D: Cerebral arachnoid cyst: A lesion of the child's brain. Neurosurg Rev 12:59-62, 1989

10. Erman T, Gocer Al, Tuna M, Ergin M, Zorludemir S, Cetinalp, E: Intracranial arachnoid cysts - clinical features and management of 35 cases and review of the literature. Neurosurgery Quarterly, 14:84-89, 2004

11. Ersahin $Y$, Kesikci $\mathrm{H}$ : Endoscopic management of quadrigeminal arachnoid cysts. Childs Nerv Syst 25:569-576, 2009, 10.1007/s00381-008-0778-2

12. Galassi E, Tognetti F, Frank F, Fagioli L, Nasi MT, Gaist G: Infratentorial arachnoid cysts. J Neurosurg 63:210-217, 1985, 10.3171/jns.1985.63.2.0210

13. Helland CA, Wester K: A population based study of intracranial arachnoid cysts: Clinical and neuroimaging outcomes following surgical cyst decompression in adults. J Neurol Neurosurg Psychiatr 78:1129-1135, 2007, 10.1136/ jnnp.2006.107995

14. Helland CA, Wester K: Intracystic pressure in patients with temporal arachnoid cysts: A prospective study of preoperative complaints and postoperative outcome. J Neurol Neurosurg Psychiatr 78:620-623, 2007, 10.1136/jnnp.2006.101865

15. Kang JK, Lee KS, Lee IW, Jeun SS, Son BC, Jung CK, Park YS, Lee SW: Shunt-independent surgical treatment of middle cranial fossa arachnoid cysts in children. Childs Nerv Syst 16:111-116, 2000

16. Martínez-Lage JF, Pérez-Espejo MA, Almagro M-J, LópezGuerrero AL: Hydrocephalus and arachnoid cysts. Childs Nerv Syst 27:1643-1652, 2011, 10.1007/s00381-011-1481-2

17. Matsuda W, Akutsu H, Miyamoto S, Noguchi S, Tsunoda T, Sasaki M, Matsumura A: Apparently asymptomatic arachnoid cyst: Postoperative improvement of subtle neuropsychological impediment -case report. Neurol Med Chir (Tokyo) 50:430-433, 2010

18. Mayr U, Aichner F, Bauer G, Mohsenipour I, Pallua A: Supratentorial extracerebral cysts of the middle cranial fossa. A report of 23 consecutive cases of the so-called temporal lobe agenesis syndrome. Neurochirurgia (Stuttg) 25:51-56, 1982, 10.1055/s-2008-1053956

19. McBride LA, Winston KR, Freeman JE: Cystoventricular shunting of intracranial arachnoid cysts. Pediatr Neurosurg 39:323-329, 2003, 10.1159/000075261
20. Pradilla G, Jallo G: Arachnoid cysts: Case series and review of the literature. Neurosurg Focus 22:E7, 2007

21. Rengachary SS, Watanabe I, Brackett CE: Pathogenesis of intracranial arachnoid cysts. Surg Neurol 9:139-144, 1978

22. Di Rocco C: Sylvian fissure arachnoid cysts: We do operate on them but should it be done? Childs Nerv Syst 26:173-175, 2010, 10.1007/s00381-009-1041-1

23. Santamarta D, Aguas J, Ferrer E: The natural history of arachnoid cysts: Endoscopic and cine-mode MRI evidence of a slit-valve mechanism. Minim Invasive Neurosurg 38: 133-137, 1995, 10.1055/s-2008-1053473

24. Schroeder HW, Gaab MR: Endoscopic observation of a slitvalve mechanism in a suprasellar prepontine arachnoid cyst: Case report. Neurosurgery 40:198-200, 1997

25. Shim KW, Lee YH, Park EK, Park YS, Choi JU, Kim DS: Treatment option for arachnoid cysts. Childs Nerv Syst 25:1459-1466, 2009, 10.1007/s00381-009-0930-7

26. Soukup VM, Patterson J, Trier TT, Chen JW: Cognitive improvement despite minimal arachnoid cyst decompression. Brain Dev 20:589-593, 1998

27. Spansdahl T, Solheim O: Quality of life in adult patients with primary intracranial arachnoid cysts. Acta Neurochir (Wien) 149:1025-1032; discussion 1032, 2007, 10.1007/s00701-007$1272-1274$

28. Tamburrini G, Dal Fabbro M, Del Fabbro M, Di Rocco C: Sylvian fissure arachnoid cysts: A survey on their diagnostic workout and practical management. Childs Nerv Syst 24:593-604, 2008, 10.1007/s00381-008-0585-9

29. Wester K: Arachnoid cysts in adults: Experience with internal shunts to the subdural compartment. Surg Neurol 45:15-24, 1996

30. Wester K: Peculiarities of intracranial arachnoid cysts: Location, sidedness, and sex distribution in 126 consecutive patients. Neurosurgery 45:775-779, 1999

31. Wester K, Hugdahl K: Arachnoid cysts of the left temporal fossa: Impaired preoperative cognition and postoperative improvement. J Neurol Neurosurg Psychiatr 59:293-298, 1995

32. Wester K, Moen G: Documented growth of a temporal arachnoid cyst. J Neurol Neurosurg Psychiatr 69:699-700, 2000

33. Wester K: Intracranial arachnoid cysts--do they impair mental functions? J Neurol 255:1113-1120, 2008, 10.1007/s00415008-0011-y

34. Zhang J, Zhao S-Y, Yuan X-H: Stereotactic cyst/ventricularperitoneal shunting for the treatment of prepontine arachnoid cyst: Case report. Surg Neurol 66:616-618; discussion $618,2006,10.1016 /$ j.surneu.2006.03.031 